\title{
UJI TOKSISITASEKSTRAK DAUN SIRSAK (Annona muricata L.) YANG BERPOTENSI SEBAGAI ANTIKANKER
}

\author{
Triyani Sumiati ${ }^{*}$, Ferry Effendi $^{1}$, ,Rina arifah puspitasari ${ }^{1}$ \\ ${ }^{1}$ Program Studi Farmasi Sekolah Tinggi Teknologi Industri dan Farmasi Bogor \\ Korespondensi: triyanisumiati@gmail.com
}

\begin{abstract}
ABSTRAK
Tanaman sirsak (Annona muricata L.) termasuk dalam familia Annonaceae.Masyarakat telah lama mengenal dan menggunakannya sebagai obat tradisional.Salah satu manfaat dari daun sirsak yaitu dapat dipakai sebagai alternatif pengobatan penyakit kanker.Sampai saat ini belum diketahui secara ilmiah apakah daun sirsak mempunyai aktivitas antikanker. Tujuan penelitian ini adalah untuk mengetahui potensi toksisitas zat bioaktif dari ekstrak etanol, etil asetat dan n-heksan daun sirsak sebagai zat antikanker dengan menggunakan metode BSLT.Penelitian ini menggunakan sebanyak 100 ekor larva udang yang digunakan sebagai objek penelitian yang secara acak dibagi dalam 3 kelompok.Tiap kelompok terdiri dari 10 ekor larva dan pengulangan dilakukan sebanyak tiga kali perkelompok.Konsentrasi ekstrak dalam media yang digunakan adalah 500, 100, 10 dan sebagai kontrol digunakan $0 \mathrm{ppm}$. Data diperoleh dengan cara menghitung jumlah larva yang mati setelah 24 jam. Data yang diperoleh kemudian ditentukan dengan menggunakan tabel analisis probit. Kadar air yang terkandung dalam simplisia adalah $6,49 \%$. Hasil dari analisis probit menunjukkan bahwa ekstrak etanol mempunyai nilai $\mathrm{LC}_{50}$ sebesar $86,45 \mathrm{ppm}$, sedangkan ekstrak etil asetat $92,81 \mathrm{ppm}$ dan ekstrak n-heksana 37601,05 ppm. Pemberian ekstrak etanol dan etil asetat daun sirsak pada percobaan ini cenderung menunjukkan adanya potensi toksisitas terhadap larva Artemia salina Leach.Ekstrak nheksana daun sirsak tidak menunjukkan adanya potensi toksisitas terhadap larva Artemia salina Leach.
\end{abstract}

Kata kunci :Daun sirsak, kanker, larva udang, Artemia salina Leach, Brine Shrimp Lethality Test, toksisitas.

\begin{abstract}
Plant soursop (Annona muricata L.) is one of the Annonaceae familia. This plant has well-known in the society environment and it has been using as a traditional medicine. One of benefits of the soursop is can used as an algernative of cancer treatment. Until now not yet known scientifically whether soursop leaves have anticancer activity.This study aims to determine the potential toxicity of bioactive substances from the ethanol extract, of ethyl acetate and n-hexane of the soursop leaves as an anticancer agent by using Brine Shrimp Lethality Test (BSLT) method. This experimental As many as 100 larvas were use as research objects which divided into 3 groups. Each group consist of 10 larvas and the group repetition were done by randomly, three times per group. The extract concentration used in medium is 500, 100, 10 and as a control 0 ppm. Data obtained from counting the number of dead larvas (letal concentration $50 \mathrm{ppm}$ ) after 24 hours treatment. Based on the data obtained from $\mathrm{LC}_{50}$ of extract ethanol, ethyl acetate and n-hexane soursop leaves then determined by using probit analysis. The water content which contained in simplicia (drifed leaves) is 6,49\%. The probit analysis results show that the ethanol extract have $\mathrm{LC}_{50}$ values of $86,45 \mathrm{ppm}, 92,81 \mathrm{ppm}$ of ethyl acetate extract and nhexane extracts $37601,05 \mathrm{ppm}$. The distribution of ethanol and ethyl acetate extracts of soursop leaves in the experiments shown any potential toxicity against Artemia salina Leach, while the n-hexane extract of soursop leaves show no any potential toxicity to against Artemia salina Leach larvas.
\end{abstract}

Keywords: leaves soursop, cancer, Brine Shrimp Lethality Test, shrimps,Artemia salina Leach, toxicity. 


\section{PENDAHULUAN}

Menurut WHO, kanker adalah istilah umum untuk satu kelompok besar penyakit yang dapat mempengaruhi setiap bagian dari tubuh. Istilah lain yang digunakan adalah tumor ganas dan neoplasma. Salah satu fitur mendefinisikan kanker adalah pertumbuhan sel-sel baru secara abnormal yang tumbuh melampaui batas normal, dan yang kemudian dapat menyerang bagian sebelah tubuh dan menyebar ke organ lain. Proses ini disebut metastasis. Metastasis merupakan penyebab utama kematian akibat kanker .

Dari tahun ke tahun penderita kanker di dunia terus bertambah. Berdasarkan data Badan Kesehatan Dunia (WHO) tahun 2010, pada tahun 2005 kematian akibat kanker di seluruh dunia mencapai 7 juta orang, 11 juta kasus baru kanker dan 25 juta orang hidup dengan kanker.Diperkirakan pada tahun 2030, kematian akibat kanker meningkat menjadi 17 juta, 27 juta kasus baru dan 75 juta orang hidup dengan kanker.Kanker menempati peringkat tertinggi sebagai penyebab kematian di negara berkembang karena usaha penyembuhan dengan obat kanker umumnya masih relatif mahal dan memiliki efek samping yang besar.

$$
\text { Pengobatan kanker dengan }
$$

menggunakantumbuh-tumbuhan di Indonesia terbukti mampu mencegah maupun mengobati kanker.Meski perlu penelitian dan pengembangan lebih lanjut, sejumlah tanaman seperti kunyit putih, tapak dara, daun dewa hingga benalu telah digunakan penderita kanker sebagai ikhtiar mengobati penyakitnya.Banyak yang berhasil sembuh sehingga pengobatan tradisional pun menjadi tumpuan harapan baru bagi para penderita kanker.Daun Sirsak juga tengah populer sebagai tanaman obat-obatan yang banyak digunakan sebagai obat antikanker.Daun sirsak (Annona muricata L.) mengandungacetogenins yang merupakan zat antikanker yang mampu melawan pertumbuhan sel abnormal pada stadium prakanker dan dapat mencegah perkembangan sel kanker.Senyawa aktif acetogenin terdapat pada bagian daun dan buah sirsak yang bermanfaat untuk menghambat dan membunuh sel kanker [1].Senyawa pada daun sirsak yang diduga memiliki khasiat antikanker adalah senyawa flavonoid [2].
Dari penelitian sebelumnya telah dilakukan penafsiran uji antioksidan atau uji penangkapan radikal bebas DPPH pada daun sirsak diperoleh nilai $\mathrm{IC}_{50} 22,52 \mathrm{ppm}$ yang menunjukan bahwa daun sirsak memiliki aktivitas antioksidan yang dapat berfungsi sebagai penghambat sel kanker [3].Hasil penelitian menyebutkan tentang uji bioaktivitas buah dan daun sirsak salah satunya sabagai antioksidan, oleh karena itu perlu dilakukan uji penafsiran pada daun sirsak untuk mengetahui pengaruh aktivitas sitotoksiknya terhadap larva udang Artemia salina Leach [4].

Uji toksisitas merupakan uji pendahuluan untuk mengamati aktivitas farmakologi suatu senyawa.Prinsip uji toksisitas adalah bahwa komponen bioaktif selalu bersifat toksik jika diberikan dengan dosis tinggi dan menjadi obat pada dosis rendah.Metode Brine Shrimp Lethality Test (BSLT) dengan menggunakan larva udang Artemia salina Leach sebagai hewan uji merupakan salah satu metode yang banyak digunakan untuk pencarian senyawa antikanker baru yang berasal dari tanaman. Larva udang memiliki kulit yang tipis dan peka terhadap lingkungannya sehingga banyak digunakan dalam uji toksisitas. Zat atau senyawa asing yang ada di lingkungan akan terserap ke dalam tubuh secara difusi dan langsung mempengaruhi kehidupannya. Larva udang yang sensitif ini akan mati apabila zat atau senyawa asing tersebut bersifat toksik. Uji toksisitas digunakan untuk mengetahui pengaruh racun yang dihasilkan oleh dosis tunggal dari suatu campuran zat kimia pada hewan coba sebagai uji pra skrining senyawa bioaktif antikanker [5].Uji toksisitas dengan metode BSLT ini merupakan uji toksisitas akut dimana efek toksik dari suatu senyawa ditentukan dalam waktu singkat, yaitu rentang waktu selama 24 jam setelah pemberian dosis uji. Hasil uji toksisitas dengan metode ini telah terbukti memiliki korelasi dengan dayasitotoksis senyawa anti kanker. Selain itu, metode ini juga mudah dikerjakan, murah, cepat dan cukup akurat [6].

Untuk mengetahui sejauh mana pengaruh pemanfaatan zat bioaktif dalam daun sirsak (Annona Muricata L.) sebagai zat antikanker maka peneliti akan melakukan pengujian terhadap larva Artemia salina 
Leachdengan menggunakan metode Brine Shrimp Lethality Test (BSLT) yang merupakan skrining awal obat antikanker.

\section{METODE PENELITIAN}

Bahan: Bahan - bahan yang digunakan pada penelitian ini adalah ekstrak daun sirsak, $\mathrm{HCl}$ $2 \%$, larutan asam encer, pereaksi Dragendrof, pereaksi Mayer, pereaksi Wagner, air panas, $\mathrm{HCl} 2 \mathrm{~N}$, etanol, etil asetat, n-heksana, serbuk $\mathrm{Zn}, \mathrm{HCl}$ pekat, asam asetat anhidrat, kloroform, asam sulfat, larva udang Artemia salina Leach, air laut, perbandingan/konsentrasi sampel $500 \mathrm{ppm}$, $100 \mathrm{ppm}, 10 \mathrm{ppm}$ dan 0 ppm sebagai kontrol kontrol (tanpa ekstrak).

Alat: Alat-alat yang digunakan dalam penelitian ini adalah timbangan analitik, tabung reaksi, labu erlenmeyer, pipet tetes, rak tabung, bejana penetasan larva, lampu penyinaran (lampu TL), plat well $2000 \mu$ l, beaker glass, bunsen, mikro pipet, pompa aerator, rotari evaporator, botol vial, kertas saring, spatel.

\section{Metode}

\section{Preparasi Sampel}

Sampel yang digunakan adalah daun sirsak (Annona Muricata L.). Sampel daun sirsak segar yang berwarna hijau dibersihkan atau disortasi, kemudian dicuci dengan air mengalir hingga bersih. Sampel daun sirsak dikeringkan dengan diangin-anginkan selama 3-5 hari. Sampel dihaluskan dengan blender serta diayak dengan pengayak ukuran 40 mesh.

\section{Penentuan Kadar Air}

Pengerjaannya dilakukan dengan cara cawan porselin dikeringkan pada suhu $105^{\circ} \mathrm{C}$ selama $3 \mathrm{jam}$, kemudian didinginkan dalam eksikator selama 30 menit dan ditimbang untuk mengetahui bobot kosong dari cawan. Sebanyak 2 gram sampel dimasukkan ke dalam cawan porselin dan dimasukkan ke dalam oven pada suhu $105^{\circ} \mathrm{C}$ selama 6 jam, kemudian didinginkan dan ditimbang kembali. Rumus perhitungan kadar air, sebagai berikut:

$$
\text { Kadar air }(\%)=\frac{a-b}{a} \times 100 \%
$$

$\mathrm{a}=$ bobot sampel sebelum pemanasan $(\mathrm{g})$

$\mathrm{b}=$ bobot sampel setelah pemanasan $(\mathrm{g})$
Pembuatan Ekstrak EtanolDaun Sirsak

Simplisia daun sirsak sebanyak 100 gram yang telah dihaluskan dan diayak, dimasukkan ke dalam 3 labu Erlenmeyerdan masing-masing ditambahkan pelarut etanol $96 \%$, etil asetat, dan $n$-heksan, masing-masing sebanyak $500 \mathrm{ml}$. Ekstraksi dengan pelarut tersebut menggunakan metode maserasi selama 3x24 jam. Setiap 12 jam dilakukan penghomogenan dengan cara menggerakkan wadah secara perlahan-lahan.Selanjutnya ekstrak disaring menggunakan corong butcher untuk memisahkanresidu dengan filtrat. Filtrat yang diperoleh selanjutnya dipekatkan dengan menggunakan rotaryevaporator pada suhu 50$70^{\circ} \mathrm{C}$.

Ekstrak kental yang diperoleh kemudian dihitung \% rendemennya dengan rumus:

$$
\begin{gathered}
\text { Rendemen }=\frac{\text { bobot ekstrak kental }}{\text { bobot serbuk }} \times 100 \% \\
\text { dimasukkan kedalam masing }- \text { masing }
\end{gathered}
$$

\section{Uji Fitokimia[7]}

a. Uji Alkaloid

Sebanyak $500 \mathrm{mg}$ sampel (ekstrak etanol $96 \%$, ekstrak etil asetat, dan ekstrak nheksan)ditambahkan $1 \mathrm{ml}$ asam klorida $2 \mathrm{~N}$ dan $10 \mathrm{ml}$ air, panaskan di penangas air selama 2 menit, dinginkan dan saring.Kemudian dibagi menjadi 3 tabung reaksi.Pada tabung pertama dimasukkan pereaksi Mayer, hasil dinyatakan (+) jika terbentuk endapan putih.Pada tabung kedua dimasukkan perekasi Dragendorff, hasil dinyatakan (+) bila terbentuk endapan merah jingga. Pada tabung ketiga dimasukkan pereaksi Wagner, hasil dinyatakan (+) bila terbentuk endapan coklat.

b. Uji Flavonoid

Sebanyak $500 \mathrm{mg}$ sampel (ekstrak etanol $96 \%$, ekstrak etil asetat, dan ekstrak nheksan) dilarutkan dalam $5 \mathrm{ml}$ air kemudian dipanaskan selama 5 menit setelah itu disaring. Filtrat ditambahkan serbuk magnesium serta $\mathrm{HCl}$ :etanol (1:1) dan amil alkohol. Hasil dinyatakan positif bila terbentuk endapan warna jingga hingga merah ungu.

c. Uji Saponin

Sebanyak $500 \mathrm{mg}$ sampel (ekstrak etanol $96 \%$, ekstrak etil asetat, dan ekstrak n- 
heksan)ditambahkan $5 \mathrm{ml}$ akuades dalam tabung reaksi.Dikocok kuat-kuat, adanya saponin ditandai dengan terbentuk busa yang stabil.

d. Uji Tanin

Sebanyak $500 \mathrm{mg}$ sampel (ekstrak etanol $96 \%$, ekstrak etil asetat, dan ekstrak nheksan)direbus dengan $10 \mathrm{ml}$ akuades dalam tabung reaksi selama 5 menit, kemudian disaring. Filtrat ditetesi $\mathrm{FeCl}_{3}$ 1\%.Uji positif ditandai dengan munculnya warna hijau kecoklatan atau biru kehitaman.

e. Uji Steroid

Sebanyak $500 \mathrm{mg}$ sampel (ekstrak etanol 96\%, ekstrak etil asetat, dan ekstrak nheksan) ditambahkan etanol kemudian dipanaskan selama 2 menit. Ekstrak disaring dalam keadaan panas kemudian filtrat diuapkan di waterbath sampai kering. Setelah kering ditambahkan $1 \mathrm{ml}$ dietil eter kemudian dihomogenasikan selanjutnya ditambahkan 1 tetes $\mathrm{H}_{2} \mathrm{SO} 4$ pekat dan 1 tetes $\mathrm{CH} 3 \mathrm{COOH}$ anhidrat.Uji positif ditandai dengan munculnya warna hijau atau biru.

\section{Persiapan Larva Udang}

Telur udang laut Artemia salina Leach ditaburkan dalam bejana penetasan yang berisi air laut dan disimpan dibawah lampu dengan sisi terbuka menghadap lampu. Setelah 24 jam, telur yang sudah menetas menjadi nauplius dipindahkan ke tempat lain, 48 jam setelah itu nauplius tersebut sudah dapat digunakan sebagai hewan uji.

\section{Persiapan Sampel}

Setiap larutan ekstrak yang telah dibuat terlebih dahulu ditimbang sebanyak 0,02 gram kemudian dilarutkan dengan air laut sebanyak $10 \mathrm{ml}$ sehingga kosentrasinya $2000 \mathrm{ppm}$ dan digunakan sebagai larutan induk. Dari larutan induk tersebut kemudian dibuat masing-masing 500 ppm, 100 ppm dan 10 ppm.

\section{Pembagian Kelompok Perlakuan}

Pada penelitian ini larva Artemia salina Leach dibagi ke dalam empat kelompok perlakuan yaitu :

a. Kelompok K adalah 10 larva udang Artemia salina Leach yang diberi ekstrak daun sirsak dengan konsentrasi $0 \mu \mathrm{g} / \mathrm{ml}$. b. Kelompok P1 adalah 10 larva udang Artemia salina Leach yang diberi ekstrak daun sirsak dengan konsentrasi $500 \mu \mathrm{g} / \mathrm{ml}$.

c. Kelompok P2 adalah 10 larva udang Artemia salina Leach yang diberi ekstrak daun sirsak dengan konsentrasi $100 \mu \mathrm{g} / \mathrm{ml}$.

d. Kelompok P3 adalah 10 larva udang Artemia salina Leach yang diberi ekstrak daun sirsak dengan konsentrasi $10 \mu \mathrm{g} / \mathrm{ml}$.

\section{Uji Brine Shrimp Lethality Test (BSLT)}

Disiapkan plat well untuk potensi masing-masing 4 konsentrasi dilakukan triplo, adapun tingkatan potensi toksisitas adalah 500 ppm, 100 ppm, 10 ppm dan 0 ppm.Kemudian diambil larva udang 10 ekor untuk masing masing konsentrasi, dimasukkan kedalam wadah larutan sampel yang akan diuji masing masing sebanyak $10 \mathrm{ml}$ dengan konsentrasi (500 ppm, 100 ppm, $10 \mathrm{ppm}$ dan 0 ppm).Vial yang sudah berisi larva udang diletakkan dibawah lampu selama 24 jam setelah itu dihitung jumlah larva yang mati pada setiap konsentrasi.Untuk mencari angka kematian dengan menjumlahkan larva udang yang sudah mati dalam setiap konsentrasi (3 vial). Sedangkan untuk mencari nilai angka larva yang hidup, maka dilakukan dengan cara menjumlahkan larva udang yang masih hidup dalam setiap konsentrasi (3 vial). Dengan menggunakan data yang diperoleh, dihitung nilai LC50 dengan analisis probit.Nilai LC50 $<1000$ ppm menunjukkan bahwa ekstrak memiliki sifat toksisitas [6].

\section{Analisa Data}

Data yang dikumpulkan adalah data primer yang didapatkan dari jumlah larva Artemia salina Leach yang mati dalam 24 jam setelah perlakuan pada tiap - tiap konsentrasi ekstrak daun sirsak. Data hasil penelitian diolah dan disajikan dalam bentuk tabel dan grafik. Dari data uji toksisitas tersebut dianalisis dengan analisa probit menggunakan tabel probit untuk mengetahui harga LC50.

\section{HASIL DAN PEMBAHASAN Simplisia}

Sampel yang digunakan pada penelitian ini adalah daun sirsak (Annona muricata L.)Simplisia daun sirsak dibuat serbuk dan diayak dengan pengayak 40 
mesh.Setelah pengayakan, serbuk daun sirsak diukur kadar airnya. Penentuan kadar air berguna untuk mengetahui batasan maksimal atau kisaran kandungan air dalam bahan. Hal ini berhubungan dengan daya simpan simplisia, sehingga jika melebihi batas yang ditentukan sangat mempengaruhi waktu kadaluarsa dari simplisia tersebut. Semakin tinggi kadar air, maka semakin mudah ditumbuhi jamur dan kapang sehingga dapat menurunkan aktivitas biologi senyawa aktif selama penyimpanan. Jumlah kadar air yang baik pada daun, yaitu $\leq 10 \%$. [7]

Hasil penetapan kadar air yang diperoleh pada penelitian ini adalah 6,49\% yang artinya kadar air ekstrak daun sirsak telah memenuhi persyaratan sehingga tidak mudah ditumbuhi jamur dan kapang, serta dapat disimpan dalam waktu yang cukup lama atakan kandungan zat dalam tumbuhan sebagai persen bahan kering.

\section{Hasil Ekstraksi Daun Sirsak}

Sampel daun sirsak diekstraksi dengan tujuan untuk memisahkan komponen kimia yang terdapat pada daun sirsak. Metode ekstraksi yang digunakan pada penelitian ini, yaitu maserasi dengan 3 pelarut yaitu etanol 96\%,etil asetat dan n-heksan.. Ketiga pelarut ini mempunyai kepolaran yang berbeda dimana etanol adalah pelarut polar, etil asetat adalah pelarut semi polar dan $\mathrm{n}$-heksan adalah pelarut non polar. Digunakannya 3 pelarut yang berbeda ini untuk mengetahui secara kualitatif di pelarut yang mana senyawa flavonoid dapat terpisahkan.Pemilihan metode maserasi dikarenakan maserasi merupakan metode yang paling mudah dan sederhana, tidak memerlukanperalatan yang khusus serta suhu yang yang digunakan rendah sehingga dapat mencegah penguraian senyawa yang tidak tahan panas.Penggunaan etanol sebagai pelarut disebabkan karena etanol bersifat polar sehingga dapat menarik senyawa-senyawa polar seperti flavonoid, saponin, tanin dan lainlain.Ekstrak yang diperoleh dari hasil ekstraksi ini dipekatkan dan dihasilkan ekstrak kental. Persen rendemennya adalah 4,63\% (ekstrak etanol), 3,27\% (ekstrak etil asetat) dan 1,65\% (ekstrak n-heksan).

\section{Hasil fitokimia Ekstrak Etanol,Ekstrak Etil Asetat dan Ekstrak n-Heksan Daun Sirsak}

Uji fitokimia dalam penelitian ini dilakukan bertujuan menganalisis keberadaan senyawa yang diduga memiliki aktivitas antikanker dalam ketiga ekstrak daun sirsak.Penapisan dilakukan terhadap golongan senyawa alkaloid, flavonoid, saponin dan tanin.Hasil uji fitokimia terhadap ekstrak etanol daun sirsak menunjukkan hasil positif pada uji flavonoid, tanin, steroid dan saponin sedangkan pada uji alkaloid menunjukkan hasil negatif yang ditandai dengan tidak adanya perubahan warna.

Pada ekstrak etil asetat daun sirsak yang menunjukkan hasil positif adalah uji flavonoid, saponin dan steroid dan hasil negatif diperoleh pada uji alkaloid dan tanin. Sedangkan uji fitokimia terhadap ekstrak nheksana daun sirsak menunjukkan hasil positif pada uji flavonoid dan steroid sebaliknya hasil negatif didapat pada uji alkaloid, tanin, dan saponin.Uji fitokimia memberikan tanda hasil yang spesifik untuk setiap ujinya.Dari ketiga ekstrak yang diperoleh menunjukan bahwa ketiga ekstrak tersebut positif mengandung flavonoid dan steroid.Flavonoid merupakan metabolit sekunder yang terdapat pada vakuola tanaman.Flavonoid memiliki banyak fungsi pada tanaman, salah satunya sebagai zat warna pada bunga. Peran lain flavonoid adalah sebagai antioksidan yang digunakan untuk menghambat pertumbuhan kanker dan mampu mengkompleks logam berat [8]. Hasil positif ini ditandai dengan adanya perubahan warna menjadi jingga.. 
Tabel 1. Hasil uji fitokimia dari simplisia dan ekstrak daun sirsak

\begin{tabular}{|c|c|c|c|c|c|}
\hline \multirow[b]{2}{*}{ No } & \multirow[b]{2}{*}{ Senyawa } & \multicolumn{3}{|c|}{ Sampel } & \multirow[b]{2}{*}{ Keterangan } \\
\hline & & $\begin{array}{l}\text { Ekstrak Etanol } \\
96 \%\end{array}$ & $\begin{array}{l}\text { Ekstrak } \\
\text { Etil } \\
\text { Asetat }\end{array}$ & $\begin{array}{l}\text { Ekstrak } \\
\text { n-heksan }\end{array}$ & \\
\hline \multirow{4}{*}{1} & Alkaloid & - & & & \\
\hline & Meyer & - & - & - & Endapan putih \\
\hline & Dragendrof & - & - & - & Endapan jingga \\
\hline & Wagner & & - & - & Endapan coklat \\
\hline 2 & Flavonoid & + & + & + & jingga \\
\hline 3 & Steroid & + & + & + & $\begin{array}{l}\text { Larutan } \\
\text { Hijau/Biru }\end{array}$ \\
\hline 4 & Tanin & + & - & - & $\begin{array}{l}\text { Larutan Hitam } \\
\text { Kehijauan }\end{array}$ \\
\hline 5 & Saponin & + & + & - & Buih Stabil \\
\hline
\end{tabular}

Keterangan : (+) : Positif, mengandung zat aktif

$(-)$ : Negatif, tidak mengandung zat aktif

\section{Hasil Uji Toksisitas dengan BSLT}

Brine Shrimp Lethality Test(BSLT)

adalah suatu metode pengujian dengan menggunaka hewan uji yaitu Artemia salina L, yang dapat digunakan sebagai bioassay sederhana untuk meneliti toksisitas akut suatu senyawa, dengan cara menentukan nilai LC50 yang dinyatakan dari komponen aktif suatu simplisia maupun bentuk sediian ekstrak dari suatu tanaman. Apabila suatu ekstrak tanaman bersifat toksik menurut harga LC50 dengan metode BSLT, maka tanaman tersebut dapat dikembangkan sebagai obat antikanker. Namun, bila tidak bersifat toksik maka tanaman tersebut dapat diteliti kembali untuk mengetahui khasiat lainnya dengan menggunakan hewan coba lain yang lebih besar dari larva Artemia salina Leach seperti mencit dan tikus secara invivo [8].

Suatu senyawa dinyatakan mempunyai potensi toksisitas jika mempunyai harga LC50 kurang dari 1000 ppm [8]. LC50 merupakan konsentrasi zat yang menyebabkan terjadinya kematian pada $50 \%$ hewan percobaan yaitu larva Artemia salina L[6]. 


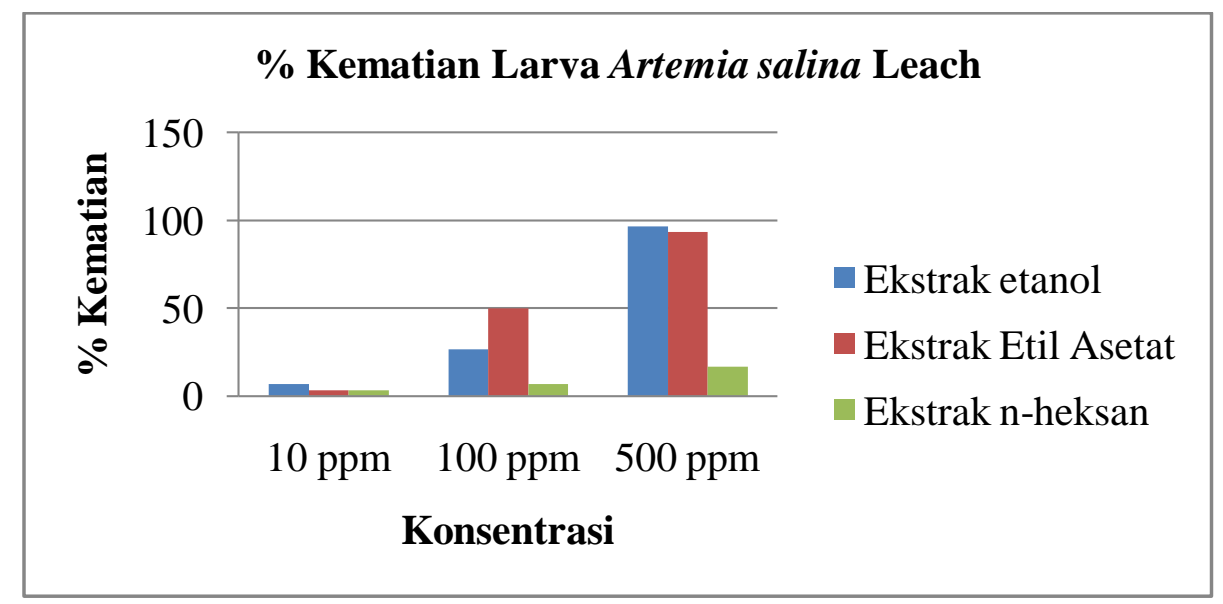

Gambar 1. Persentase Kematian larva Artemia salina Leach dengan konsentrasi 10, 100 dan 500 ppm pada ekstrak etanol, etil asetat dan n-heksana daun sirsak

Dari grafik kematian diatas dapat dilihat persentase kematian larva dari ekstrak daun sirsak pada konsentrasi 10 ppm yang paling tinggi adalah pada ekstrak etanol daun sirsak yaitu sebesar $6,67 \%$. Sedangkan pada ekstrak etil asetat dan n-heksana menunjukkan persentase kematian larva dengan hasil yang sama pada konsentrasi 10 ppm yaitu 3,33\%. Pada konsentrasi 100 ppm persentase kematian larva paling tinggi ditunjukkan pada ekstrak etil asetat daun sirsak yaitu sebesar $50 \%$ sedangkan persentase paling rendah terdapat pada ekstrak n-heksana yaitu sebesar $6,67 \%$. Pada konsentrasi 500 ppm persentase kematian larva paling tinggi ditunjukkan pada ekstrak etanol daun sirsak yaitu sebesar $96,67 \%$ dan persentase kematian paling rendah terdapat pada ekstrak n-heksana dengan nilai $16,67 \%$ kematian. Hal ini menunjukkan bahwa dari masing - masing ekstrak tersebut apabila konsentrasi larutan semakin tinggi maka persentase kematian juga akan meningkat. Dari grafik diatas dapat dilihat bahwa ekstrak etanol daun sirsak mempunyai potensi daya bunuh larva yang paling besar kemudian yang kedua pada ekstrak etil asetat sedangkan ekstrak nheksana daun sirsak mempunyai potensi daya bunuh yang rendah.

Hasil dari analisis probit menunjukkan harga LC50 dari ekstrak etanol adalah 86,45 ppm yang masuk dalam katagori sangat toksik [9]. Ekstrak etil asetat memiliki harga LC50 sebesar 92,81 ppm termasuk katagori sangat toksik (Anderson et al., 1991) dan dari ekstrak n-heksana daun sirsak adalah 3701,05 ppm sehingga dapat dikatakan bahwa ekstrak n heksana daun sirsak tidak memiliki potensi toksisitas karena harga LC50 lebih dari 1000 ppm. Menurut Meyer et al., melaporkan bahwa suatu ekstrakmenunjukkan aktivitasantikankerdalam ujitoksisitas jika ekstrak dapat menyebabkankematian 50\% hewan uji pada konsentrasi kurang dari1000ppm.Pada penelitian ini didapatkan bahwa ekstrak etanol dan ekstrak etil asetat daun sirsak mempunyai potensi toksisitas. Hal ini berkaitan dengan senyawa yang terdapat dalam daun sirsak yaitu flavonoid, dimana pada kadar tertentu memiliki potensi toksisitas akut serta dapat menyebabkan kematian larva Artemia salina $\mathrm{L}$.

Mekanisme flavonoid sebagai antikanker ada beberapa teori. Pertama, flavonoid sebagai antioksidan [10] Kedua, flavonoid sebagai penghambat proliferasi tumor/kanker yang salah satunya dengan menghibisi aktivitas protein kinase sehingga menghambat jalur transduksi sinyal dari membran ke sel inti. Ketiga, dengan menghambat aktivitas reseptor tirosin kinase karena aktivitas reseptor tirosin kinase yang meningkat berperan dalam pertumbuhan keganasan. Keempat, flavonoid juga berfungsi untuk mengurangi resistensi tumor terhadap agen kemoterapi [11].

\section{SIMPULAN}

Hasil penelitian menunjukkan bahwa pemberian ekstrak daun sirsak pada pengujiantoksisitas menunjukkan nilai LC50 sebesar 86,45 ppm pada ekstrak etanol 96\%, nilai LC50 sebesar 92,81 ppm pada ekstrak etil asetat, dan nilai LC50 sebesar 37601,05 ppm pada ekstrak n-heksan. Dengan demikian 
ekstrak etanol daun sirsak dan ekstrak etil asetat daun sirsak pada percobaan ini menunjukkan adanya potensi toksisitas terhadap larva Artemia salina Leach sedangkan ekstrak n-heksana menunjukkan tidak adanya potensi toksisitas.

\section{SARAN}

Perludilakukanisolasi senyawa aktif yang bersifat sitotoksik.

\section{DAFTAR PUSTAKA}

[1] Flora, E. 2008. Tanaman Obat Indonesia Untuk Pengobatan. http://www.indonesianherbal.blogspot.com/2008/11/tanamanobat-indonesia-untuk pengobatan.html. [Diakses : 1 Mei 2011]

[2] Markham, K. R. 1988. Cara Mengidentifikasi Flavonoid. Bandung : Penerbit ITB

[3] Desmiaty, Yesi. 2012. Uji Pendahuluan Aktivitas Antioksidan Terhadap Ekstrak Etanol Daun Sirsak dan Batang Brotowali. [skripsi]. Jakarta : Fakultas Farmasi Universitas Pancasila.

[4] Adjie, S. 2011. Dahsyatnya sirsak tumpas penyakit. Yogyakarta

[5] Hosettmann, K. 1991. Methods in Plant Biochemistry. Vol 6. New York : Academic press.

[6] Meyer, B. N., Ferrigni, N. R., Putman, J. E., Jacbsen, L. B., Nicols, D. E., and
McLaughlin, J. L. 1982. Brine Shrimp : A Comvenient general Bioassay For Active Plant Constituents. Plant Medica, 45, 31 - 45.

[7] Harborne, 1996. Metode Fitokimia Penuntun Cara Modern Menganalisis Tumbuhan. Terbitan kedua. Terjemahan K. Padmawinata dan 1 . Soediro. Bandung: ITB.

[8] Carballo JL, Hernandez-Inda ZL, Perez P. Garcia-Gravaloz MD. 2002. Comparison between two brine shrimp assays to detec in vitro cytotoxicity in marine natural products. BMC Biotechnology. 2002;2: 1472-6570

[9] Anderson, J. E., 1991. A Blind Comparison of Simple Bench-Top Bioassays and Human Tumour Cell Cytotoxicities as Antitumor Prescreens. Phytochem. J Anal (2).

[10] Risky Erila R. 2010. Uji Toksisitas Akut Ekstrak Etanol Daun Kamboja (Plumeria alba L.) Terhadap Larva Artemia salina Leach Dengan Metode Brine Shrimp Lethality Test [skripsi]. Semarang : Universitas Diponegoro, Fakultas Kedokteran.

[11]Demeule M et al. 2002. Grean tea catechin as novel antitumor and antiangiogenic compounds. Curr Med Chem Anticancer Agent. Jul : 2(4) : 441-63 